\title{
Ochratoxin contamination in pig feed from pig farming centres in Indonesia
}

\author{
Variena Intansari, Agustin Indrawati*, Sri Murtini \\ Department of Animal Disease and Veterinary Public Health, Faculty of Veterinary Medicine, IPB University, Bogor, Indonesia
}

Received 15th December 2020 / Accepted 5th May 2021

\begin{abstract}
Ochratoxin A (OTA) is the most common toxin found in nature. Ochratoxin is a metabolic product by Aspergillus spp. and Penicillium spp. OTA produced by many Aspergillus or Penicicillium species that contaminate animal feeds can cause diseases. This study aims to determine the incidence of ochratoxin contamination in pig feed such as pellets, meat bone meal (MBM), and tofu by products. The sampling method used the disease detection formula to collect 36 samples 36 taken from several regions. North Sumatra, East Nusa Tenggara, Bali, Bulan Island, Solo, Lampung, Banten, Bogor and Jakarta. Ochratoxin contamination in animal feed was detected based on the Enzyme Linked Immunosorbent Assay (ELISA) using Agraquant ${ }^{\circledR}$ ochratoxin assay following the manufacturer's protocol. The analysis showed that 6 of the 36 samples $(16.7 \%)$ were tested positive for ochratoxin contamination. Pellets and MBM were the feed and feedstuff which were found to contain ochratoxin. The concentration of ochratoxin in MBM was below the limit set by the National Agency of Drug and Food Control of the Republic of Indonesia (5 $\mathrm{ppb})$. The high contamination of ochratoxin was found in pellets from Lampung $(19 \mathrm{ppb})$. The fungi found to dominates the culture media and come from pellet feed were Aspergillus flavus and Aspergillus niger.
\end{abstract}

Keywords: A. niger, feed, ochratoxins, pig

\section{INTRODUCTION}

Indonesia has a number of pig farms located in the regions of Bali, North Sumatra, Kalimantan, East Nusa Tenggara, Sulawesi, and Papua. East Nusa Tenggara, North Sumatra and Bali have the highest number of pig populations compared to other regions (Ditjen, 2018). Pig productivity is determined by the management and feed quality. Pig feed is classified according to its purpose into three categories: starter, grower, and finisher. These three categories contain protein and carbohydrate components such as fish meal, corn, groundnut meal, soybean meal, tofu by product and livestock forage. Standard pig feed containing fish meal, rice bran, and soybean meal produces profitable growth compared to commercial feed (Rumerung, 2015).

Small farms generally prepare feed by making their own rations. Feeding material containing grains can easily be contaminated by pathogenic fungi (Bahri, 2015). Contamination can occur from feed material or material that has been formulated. Fungal contamination in animal feeds can causes damages to the feed structures. Damage during storage can occur physically, chemically, and biologically (Bryden, 2012). Fungal contamination can reduce nutrient content in feed and may threat animal safety, leading to food safety problems.

\footnotetext{
*Author for correspondence: Agustin Indrawati, Department of Animal Disease and Veterinary Publich Health, Faculty of Veterinary Medicine, IPB University, Bogor, Indonesia. Email - titin.seta@gmail.com
} 
Feeds contaminated with fungi can cause serious problems in animal safety and health. Fungi that contaminate feed can produce toxins such as animal mycotoxicosis and leave residues in livestock products, which can also be dangerous to human health. Residues have been found in meat and milk from livestock which consumed feed containing mycotoxins (Bryden, 2012; Widiastuti, 2014). Mycotoxins are secondary metabolites produced by Penicillium, Fusarium, Aspergillus, and Alternaria (Repeckiene et al., 2013). Mycotoxins commonly found in feed include aflatoxin, ochratoxin, fumonisin, zearalenone, deoxynivalenol, and T2 toxin (Bahri, 2014).

Ochratoxin can be produced by several fungi, such as Aspergillus ocbraceus and A. niger. A. ochraceus naturally grows on decaying seeds and plants. Studies have shown that one ochratoxinproducing fungus known as $A$. ochraceus can be found in animal feed such as corn, wheat, barley, and beans (Denli, 2015). Another fungus that can produce ochratoxin is $A$. niger. A study using 73 samples of $A$. niger showed that approximately $14 \%$ of the samples produced ochratoxin A (Pfohl-leszkowicz, 2007). Ochratoxin one type of mycotoxins, consists of three types, ochratoxin A (OTA), ochratoxin B (OTB) and ochratoxin C (OTC). The most common type of ochratoxin found in nature is OTA. OTA is one of the most toxic and widely found in agricultural products and animal feed products. Animals that consume feeds contaminated with OTA can have nephrotoxins and hepatoxin (Denli, 2015). Other studies have also shown that in pigs OTA can cause nephritis, necrosis of the liver and lymphatic tissue (Pfohl-leszkowicz, 2007; Zhang et al., 2015). Approximately $25 \mu \mathrm{g} \cdot \mathrm{kg}^{-1}$ of OTA added in pig feed can leaves a residue of more than $1 \mathrm{mg} \cdot \mathrm{kg}^{-1}$ in the liver, heart, and muscles, exceedings the safe limit set by European Union (Malagutti et al., 2005).

The prevalence of mycotoxicosis due to ochratoxin contamination in North Asia, Southeast Asia and South Asia in feed samples was $24 \%, 9 \%$, and $50 \%$, respectively (Binder, 2007). The prevalence of mycotoxicosis due to ochratoxin in pigs from Indonesia has not been reported. This is perhaps due tothe lack of information regarding ochratoxin contamination in pig feed. The ochratoxin contamination that has been reported is limited to chicken feed. Therefore, the study aims to detect the content of ochratoxin contained in pig feed.

\section{MATERIALS AND METHODS}

The materials were pig feed samples obtained from several livestock centres in Indonesia, $70 \%$ alcohol, Dichloran 18 Glycerol Agar (DG18) media, Sabourand Dextrose Agar (SDA), methanol, and ochratoxin standard (Agraquant ${ }^{\circledR}$ ochratoxin assay). The tools were petri dishes, autoclave, Bunsen, incubator, plastic containers, microscope, digital scales, shakers, $250 \mathrm{~mL}$ Erlenmeyer, aluminium foil, high speed blender with a capacity of $500 \mathrm{~mL}$, Whatman no. 1, and ELIS $A$ reader.

\section{Sampling method and sample size}

The pig feed samples were obtained from livestock centres in North Sumatra, East Nusa Tenggara, Bali, Bulan Island, Solo, Lampung, Banten, Bogor and Jakarta (Table 1). The sample size was determined at $95 \%$ confidence level using the Thrusfield method (Thrusfield, 2006). The formula used was: $\mathrm{n}=4 \mathrm{PQ} / \mathrm{L}^{2}$, where $\mathrm{n}=$ sample size, $\mathrm{P}=$ prevalence assumption, $\mathrm{Q}=1$ $\mathrm{P}$ and $\mathrm{L}=$ the desired error magnitude. The amount of prevalence is $10 \%$, while the desired error is $10 \%$.

\section{Sample preparation}

The samples were ground and passed through a 20 -mesh sieve $(0.84 \mathrm{~mm})$. Then, the subsample portion was thoroughly mixed. Approximately 20 $\mathrm{g}$ of ground samples was placed into a clean jar, which was then tightly sealed. Following this, approximately $100 \mathrm{~mL}$ of $70 / 30(\mathrm{v} / \mathrm{v})$ methanol solution was added into a jar, and the jar was then sealed. The sample and extraction solution was 1:5. The samples were shaken or blended for three minutes. Lastly, the samples were allowed to settle and filtered from the top layer of extract through a Whatman No.1 filter. The filtrate was collected afterwards.

\section{Ochratoxin A assay by ELISA}

The basic principle of the ELISA test is a reaction between an antigen and antibodies. The 
procedure was performed according to Agraquant ${ }^{\circledR}$ ochratoxin assay instruction manual. An appropiate number of blue/green bordered dilution strips were placed in a microwell strip holder. Next a serial dilution process was performed as follows: $0,2,5,20 \& 40 \mathrm{ppb}$ and 36 filtrate samples. Following this, an equal number of antibody-coated microwell strips were placed in a microwell holder. Approximately $200 \mu \mathrm{l}$ of conjugate was dispensed into each blue/greenbordered dilution well. After that $100 \mu \mathrm{l}$ of each standard or sample was added into the appropriate dilution well containing the $200 \mu \mathrm{l}$ of conjugate. The solution was mixed by pipetting it up and down three times, and $100 \mu \mathrm{l}$ content from each dilution well was immediately transferred into the corresponding antibody coated microwell, which was then incubated at room temperature for 10 minutes. After that the content of the microwell strips was removed. The washing steps were done by filling each microwell with distilled water and then dumping the water from the microwell strips. These steps were repeated four times for a total of five steps afterwards. Several layers of absorbent paper towel were laid on a flat surface, and the microwell strips were tapped on the towels to remove as much residual water as possible after the fifth wash. Following this, $100 \mu$ of substrate was added into each microwell strip, and it was incubated at room temperature for 5 minutes. Approximately $100 \mu \mathrm{l}$ of stop solution was added into each microwell strip afterwards. The absorbances were detected using a microplate reader in a $450 \mathrm{~nm}$.

\section{Fungal isolation}

The fungal isolation step was conducted using serial dilutions ranging from $10^{-1}$ to $10^{-5}$ (Dharmaputra et al, 2013). Approximately $25 \mathrm{~g}$ of pig feed was diluted in $250 \mathrm{~mL}$ sterile distilled water. $1 \mathrm{~mL}$ dilution was then poured into a petri dish containing Dichloran 18 Glycerol Agar (DG18) media.

\section{Fungal macroscopic identification}

Each fungal colony grown on Dichloran 18 Glycerol Agar (DG18) media was purified, and incubated for 7 days. The macroscopic observations included colony colour, colony diameter, radial lines from the centre of the colony to the edge of the colony, and concentrations of circles. The fungal macroscopic and microscopic identification process referred to Pitt (1997) and Ganjar et al. (1999).

\section{Fungal microscopic observation}

The fungal microscopic identification used the Riddel method of slide culture. The glass object and cover glass were inserted into a petri dish which had been sterilised using an autoclave. The sterile SDA media on petri dishes were cut into cubical shapes and placed using an inoculating needle on a glass slide that had been sterilised. Spores that had been grown were inoculated on each side of the SDA in the form of cubes using an inoculating needle, and then covered with a glass cover and incubated at $35^{\circ} \mathrm{C}$ for 48 hours. The glass cover after incubation was then transferred to the glass of a sterile object which had been given a Lactophenol cotton blue dye and was then observed under a microscope.

Table 1. Quantity of sample from areas in Indonesia.

\begin{tabular}{lllllc}
\hline No & Area & Pellet & Tofu By-Product & Meat Bone Meal & Total \\
\hline 1 & North Sumatera & 2 & - & - & 2 \\
2 & East Nusa Tenggara & 5 & - & - & 5 \\
3 & Bali & 3 & - & - & 3 \\
4 & Bulan Island & 3 & - & - & 3 \\
5 & Solo & 2 & - & & 2 \\
6 & Lampung & 2 & - & - & 2 \\
7 & Banten & 1 & 1 & - & 2 \\
8 & Bogor & & 2 & - & 2 \\
9 & Jakarta & - & - & 15 & 15 \\
\hline & Total &
\end{tabular}


Table 2. Ochratoxin assay for pig feed by ELISA.

\begin{tabular}{lllll}
\hline Type & Total & Positive & Negative & Percentage \\
\hline Pellet & 18 & 4 & 14 & 28.6 \\
Meat Bone Meal & 15 & 2 & 13 & 15.4 \\
Tofu By-product & 3 & 0 & 3 & 0 \\
\hline Sample total & 36 & 10 & 26 & 16.7 \\
\hline
\end{tabular}

\section{RESULTS}

\section{OTA in feed}

The test on ochratoxin contamination in pig feed material using ELISA showed that 6 of 36 feed samples $(16.7 \%)$ contained ochratoxin contaminant. Approximately $28.6 \%$ of the pellets from several areas showed higher results as compared to the MBM material $(15.4 \%$ ) (Table 2).

The MBM results in a positive incidence of ochratoxin contamination were $15.4 \%$. This could have been caused by the animals used as raw materials which contained ochratoxin A (OTA). The concentration of OTA contamination in the MBM sample tested using a competitive ELISA ranged from 2.22 to $2.89 \mathrm{ppb}$.

\section{Ochratoxin A producing fungi}

Variable results were shown in the culture tests DG18 media. The isolation and identification of the total 36 samples total showed that 19 samples contained Aspergillus flavus, 24 samples contained $A$. fumigatus and $A$. niger, three samples contained Penicillium spp., and three samples contained Rhizopus sp. The presence of the fungi could be seen both macroscopically and microscopically. The samples in each dilution were also grown by several other fungi (Table 3).

\section{DISCUSSION}

The pellet feed showing positive results came from Bali, Bulan Island, Lampung, and Banten. The highest concentration of ochratoxin contamination in pellets came from Lampung at 19 ppb (Table 4). Ochratoxin contamination may have occurred during storage due to the humid storage location, which promotes fungal growth. Feed contamination may be affected by several environmental conditions during storage such as water activity, temperature, specificity of fungal strains, and unstable toxigenic properties (Atanda et al., 2011).

Several conditions such as humidity and temperature during storage may cause growth, which in turn lead fungi to produced ochratoxin. The optimumctemperature during storage ranges between $28^{\circ} \mathrm{C}$ and $34^{\circ} \mathrm{C}$, while $82-90 \%$ humidity is optimum for the growth of fungi producing ochratoxin. The optimum temperature for Aspergillus sp. to produce toxin is between $25^{\circ} \mathrm{C}$ and $32^{\circ} \mathrm{C}$, humidity $85 \%$, and moisture content 18\% (Mousa, 2013).

The MBM samples were tested positive for containing OTA contamination. This was allegedly due to the raw materials containing OTA. The presence of OTA was found in dairy products derived from cows with a concentration of 5.0-6.6 ng/L (Boudra et al., 2007). The high incidence rate was suspected because the livestock used as animal feed ingredients containing OTA residues. OTA was found in the serum of pigs consuming contaminated feed with a concentration in the kidney higher than that in the liver (Zhang et al., 2015). Pigs have been shown to be more sensitive to ochratoxin than other animals. The OTA concentration in the MBM samples was below the limit determined by the National Agency of Drug and Food Control of the Republic of Indonesia which was $5 \mathrm{ppb}$ for raw materials (BPOM, 2009). Feed with OTA concentration below the maximum limit was deemed safe for consumption by livestock.

Our study has shown that only one samples contaminated with OTA in the feed derived from tofu by-products. The concentration does not exceed the maximum contamination limit, meaning that the pulp remained safe to be consumed by livestock. The incidence of OTA contamination found in tofu by-products wias lower in concentration than that in MBM. It is perhaps because tofu by-products are not stored 
for a long time and commonly given in a fresh condition.

MBM cultures collected from January to March were, dominated by Aspergillus species including $A$. flavus, $A$. fumigatus, and $A$. niger. Fbd sample was dominated by $A$. niger and also Penicillium sp. This was thought to result in the positive ochratoxin contamination results in the $\mathrm{MBM}$ at $2.89 \mathrm{ppb}$. A. niger has the potential to produce OTA even though its concentration is not as large as $A$. ochraceus (Abarca et al., 2003). Fungal contaminant in addition to Aspergillus also has Penicillium sp., which has the potential to produce OTA. $P$. verrucosum and $P$. citrinum are fungi from the Penicillium group that can produce OTA (Taniwaki, et al., 2002).

$A$. flavus (Figure 1 ) and $A$. niger (Figure 2) are fungi that dominate culture media and come from the pellet feed. A. flavus is commonly found in feed material (Ahmad, 2009). Feed from Lampung contained A. flavus, A. niger, A. fumigatus, and Penicillium sp. The feed also produced the highest ochratoxin contamination compared to the other feed samples. Aspergillus sp. and Penicillium sp. are fungi that are able to produce ochratoxin and can cause nephrotoxic, hepatoxic, carcinogeni, teratogenic, and immunosuppressive (Wang et al., 2016).

Table 3. Fungal contamination with negative Ochratoxin Assay using ELISA.

\begin{tabular}{|c|c|c|c|}
\hline Type & $\begin{array}{l}\text { Sample } \\
\text { code }\end{array}$ & Fungal Contamination & $\begin{array}{l}\text { Fungal Population } \\
\text { CFU/mL }\end{array}$ \\
\hline \multirow[t]{14}{*}{ Pellet } & 1. Nta & A. flavus, Synchepalastrum sp. & $1.5 \times 10^{4}$ \\
\hline & 2. $\mathrm{Ntb}$ & A. flavus, $A$. fumigatus & $4 \times 10^{4}$ \\
\hline & 3. Ntc & A. flavus, $A$. niger & $6.5 \times 10^{4}$ \\
\hline & 4. Ntd & $\begin{array}{l}\text { A. flavus, } A \text {. niger, Fusarium sp., } A \text {. } \\
\text { fumigatus }\end{array}$ & $8 \times 10^{4}$ \\
\hline & 5. Nte & A. niger, A. fumigatus & $1.5 \times 10^{4}$ \\
\hline & 6. Sla & A. niger, $A$. flavus & $2.5 \times 10^{4}$ \\
\hline & 7. Slb & A. niger, $A$. flavus, $A$. fumigatus & $1 \times 10^{3}$ \\
\hline & 8. Mda & A. niger & $8.5 \times 10^{3}$ \\
\hline & 9. $\mathrm{Mdb}$ & A. niger, A. fumigatus & $2 \times 10^{4}$ \\
\hline & 10. Bna & $\begin{array}{l}\text { Cladosporium sp., Fusarium sp., A.niger, A. } \\
\text { flavus }\end{array}$ & $5 \times 10^{3}$ \\
\hline & 11. Bnc & $\begin{array}{l}\text { Fusarium sp., } A \text {. niger, Cladosporium sp., } A \text {. } \\
\text { fumigatus }\end{array}$ & $6 \times 10^{4}$ \\
\hline & 12. Blb & A. niger, A. fumigatus & $18 \times 10^{4}$ \\
\hline & 13. Blc & A. niger, $A$. flavus & $5 \times 10^{3}$ \\
\hline & 14. Tpa & A. flavus, $A$. niger, Fusarium sp., A. fumigatus & $114 \times 10^{4}$ \\
\hline \multirow[t]{13}{*}{ Meat Bone Meal } & 1. Jna & A. flavus, Fusarium sp. & $5 \times 10^{3}$ \\
\hline & 2. Jnb & A. fumigatus, Fusarium sp. & $5 \times 10^{3}$ \\
\hline & 3. $\mathrm{Fba}$ & A. niger, $A$. flavus, $A$. fumigatus & $5 \times 10^{2}$ \\
\hline & 4. $\mathrm{Fbb}$ & A. niger, $A$. flavus, $A$. fumigatus & $3 \times 10^{3}$ \\
\hline & 5. Fbc & A. niger, $A$. flavus, $A$. fumigatus & $3.5 \times 10^{3}$ \\
\hline & 6. Fbe & A. niger, A. fumigatus, Fusarium sp. & $1 \times 10^{4}$ \\
\hline & 7. $\mathrm{Mrb}$ & A. flavus & $5 \times 10^{3}$ \\
\hline & 8. Mrc & A. niger, A. flavus, A. fumigatus & $5 \times 10^{3}$ \\
\hline & 9. Mrd & A. fumigatus & $2 \times 10^{4}$ \\
\hline & 10. Mre & A. flavus, A. fumigatus & $5 \times 10^{3}$ \\
\hline & 11. Mrf & A. flavus, $A$. fumigatus & $5 \times 10^{2}$ \\
\hline & 12. Mrg & A. niger, $A$. fumigatus & $1 \times 10^{4}$ \\
\hline & 13. Mrh & A. fumigatus, $A$. flavus & $5 \times 10^{2}$ \\
\hline \multirow[t]{3}{*}{ Tofu By-Product } & 1. Bga & Rhiropus sp. & $91 \times 10^{4}$ \\
\hline & 2. $\mathrm{Bgb}$ & Rhizopus sp. & $51.5 \times 10^{4}$ \\
\hline & 3. $\mathrm{Tpb}$ & Rhizopus sp. & $4.5 \times 10^{4}$ \\
\hline
\end{tabular}


Table 4. Fungal contamination with positive Ochratoxin Assay using ELISA.

\begin{tabular}{|c|c|c|c|c|}
\hline Type & $\begin{array}{l}\text { Sample } \\
\text { code }\end{array}$ & $\begin{array}{l}\text { Positive } \\
\text { OTA }\end{array}$ & Contaminated fungi & $\begin{array}{l}\text { Fungal Population } \\
\text { CFU/mL }\end{array}$ \\
\hline \multirow[t]{4}{*}{ Pellet } & 1. Bla & 4.33 & A. niger, $A$. fumigatus & $5 \times 10^{2}$ \\
\hline & 2. Bnb & 3.44 & $\begin{array}{l}\text { Fusarium sp., } A \text {. niger, } A \text {. flavus, } A \text {. } \\
\text { fumigatus }\end{array}$ & $1 \times 10^{3}$ \\
\hline & 3.Lpa & 2.22 & A. niger, A. flavus, Penicillium sp. & $1 \times 10^{3}$ \\
\hline & 4. Lpb & 19 & A. fumigatus, $A$. niger, Penicillium $\mathrm{sp}$ & $2.5 \times 10^{3}$ \\
\hline \multirow[t]{2}{*}{ Meat Bone Meal } & 1.Fbd & 2.89 & A. niger, A. fumigatus, Penicillium sp. & $1 \times 10^{3}$ \\
\hline & 2. $\mathrm{Mra}$ & 2.29 & A. niger, $A$. fumigatus & $2.5 \times 10^{3}$ \\
\hline
\end{tabular}

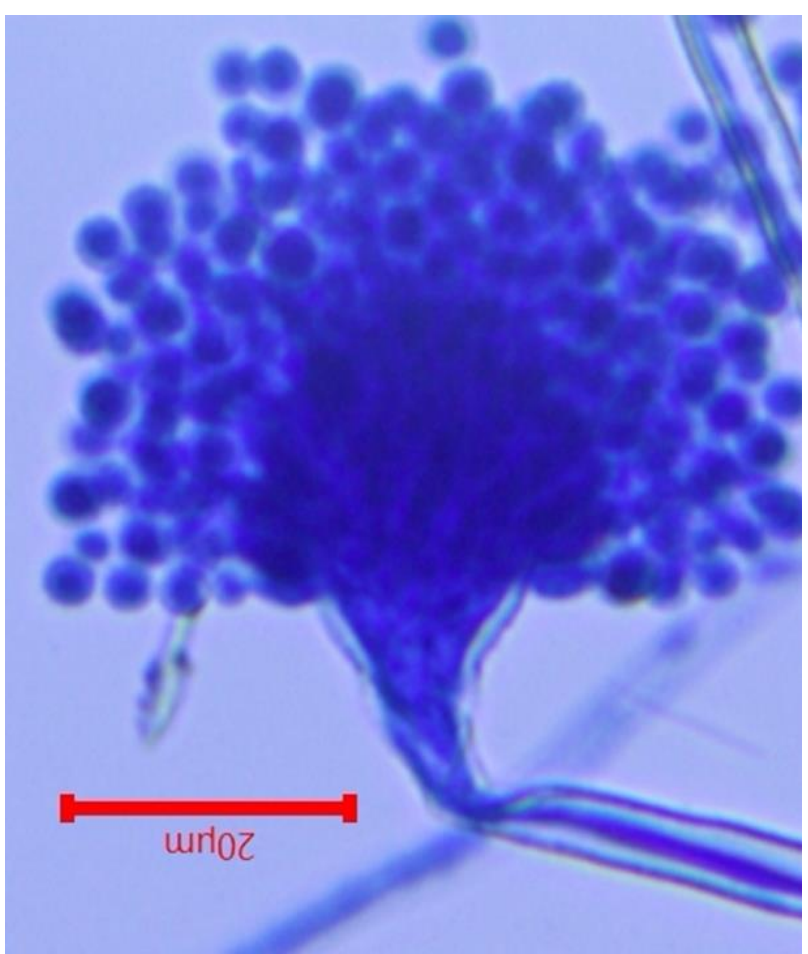

Figure 1. Aspergillus flavus.

Ochratoxin concentration in the MBM and tofu by-products was less than $5 \mathrm{ppb}$ and therefore may not cause serious problems. Ruminants can detoxify ochratoxin, unlike pigs that can leave residues in livestock products. OTA residues in pigs can be found in the kidney, liver, and muscle tissues (Bataccone et al., 2010). Symptoms that may be caused include decreased appetite, diarrhoea, polyuria, and weight loss. Detoxification failure by animals can result in reproductive disability and even death (Wang et al., 2016).

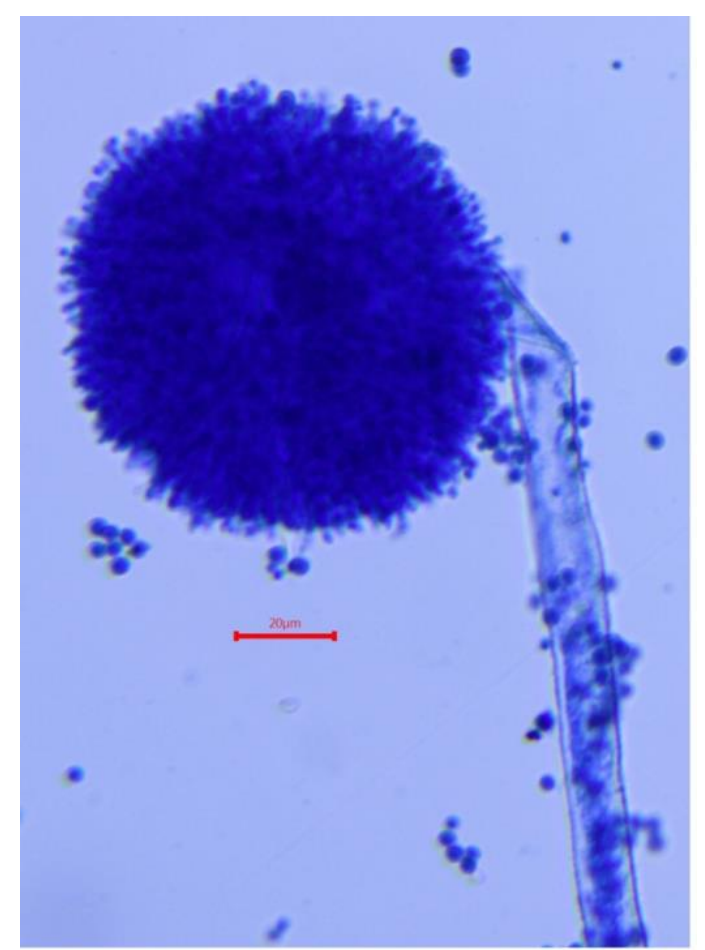

Figure 2. Aspergillus niger.

\section{CONCLUSION}

The incidence rate of OTA contamination produced by $A$. niger and Penicillium spp. in the feed pellets was $28.6 \%$ higer than that in the MBM and tofu by-products. A. niger was the most common fungus producing OTA, and was detected in 24 feed samples, while Penicillium spp. Was present in three pellet feed samples. Other fungi that produce mycotoxins were also found in feeds such as $A$. flavus, $A$. fumigatus, and Fusarium spp. 


\section{ACKNOWLEDGEMENTS}

The authors gratefully acknowledge the Department of Animal Disease and Veterinary Health, Faculty of Veterinary Medicine, Bogor Agricultural University (IPB), Indonesia for the laboratory facilities. The authors did not receive any direct funding in the completion of the present work

\section{REFERENCES}

Abarca M. L., Bragulat M. R., Castella G., \& Cabanes F. J. 2003. Ochratoxin A production by strain of Aspergillus niger var.nig. Applied and Environmental Microbiology 64: 2650-2652.

Ahmad R. Z. 2009. Cemaran kapang pada pakan pengendalinya. Journal Balitbangtan 28(1): 1-21.

Atanda S. A., Pessu P. O., Agoda S., Isong I. U., Adekalu O. A., Echendu M. A., \& Falade T. C. 2011. Fungi and mycotoxins in stored foods. African Journal of Microbiology Research 5(25): 4373-4382.

Bahri S. 2015. Toksikologi veteriner: Tanaman beracun, mikotoksin, pestisida dan logam berat. IPB Press.

Bataccone G., Nudda A., \& Pulina G. 2010. Effect of ochratoxin A on livestock production. Toxins (Basel) 2(7): 1796-1824.

Binder E. M., Tan L. M., Chin L. J., Handl J., \& Richard J. 2007. Worldwide occurrence of mycotoxins in commodities, feeds and feed ingredients. Animal Feed Science and Technology 137: 265-282.

Boudra H., Barnouin J., Dragacci S., \& Morgavi D. P. 2007. Aflatoxin M1 and ochratoxin A in raw bulk milk from French dairy herds. Journal of Dairy Science: 3197-3201.

[BPOM] Badan Pengawasan Obat dan Makanan. 2009. Peraturan Kepala Badan Pengawasan Obat dan Makanan Nomor HK.00.06.1.52.4011 tahun 2009 tentang Penetapan Batas Maksimum Cemaran Mikroba dan Kimia dalam Makanan. Jakarta (ID): BPOM.

Bryden W. L. 2012. Mycotoxin contamination of the feed supply chain: Implications for animal productivity and feed security. Animal Feed Science and Technology 173(1-2): 134-158.

Budaarsa K., Puger A. W., \& Suasta I. M. 2016. Ekplorasi komposisi pakan tradisional babi Bali. Fakultas Peternakan Universitas Udayana. ISSN : 0853-8999.

Denli M. 2015. Implications of mycotoxins in livestock feeds. Agrolife Scientific Journal: ISSN 2285-5718.

Dharmaputra O. S., Ambarwati S., Retnowati L., \& Windayarani A. 2013. Kualitas fisik, populasi Aspergillus flavus, dan kandungan aflatoksin B1 pada biji kacang tanah mentah. Jurnal Fitopatologi Indonesia 9(4): 99-106.

Ditjen P. K. H. 2018. Statistik, peternakan dan kesehatan hewan 2018. Jakarta (Indonesia): Direktorat Jenderal Peternakan dan Kesehatan Hewan.

Ganjar I., Samson R. A., van den Tweel-Vermeulen K., Oetari A., \& Santosa I. 1999. Pengenalan kapang tropik. Jakarta (ID): Universitas Indonesia.

Gizachew D., Szonyi B., Tegegne A., Hanson J., \& Grace D. 2016. Aflatoxin contamination of milk and dairy feeds in the Greater Addis Ababa milk shed, Ethiopia Food Control 59: 773-779.
Malagutti L., Zannotti M., Scampini A., \& Sciaraffia. 2005. Effects of ochratoxin A on heavy pig production. Animal Research 54(3) :179-184.

Mousa W., Ghazali F. M., Jinap S., Ghazali H. M., \& Radu S. 2013. Modeling growth rate and assessing aflatoxins production by Aspergillus flavus as a function of water activity and temperature on polished and brown rice. Journal Food Science 78(1): 56-63.

Pfohl-leszkowicz A. \& Manderville. 2007. Ochratoxin A: An overview on toxicity and carcinogenicity in animals and human. Moleculer Nutrition and Food Research 51: 61-99.

Pitt J. I. \& Hocking A. D. 1997. Fungi and food spoilage. New York (US): Springer Science.

Repeckiene J., Levinskaite L., Paskevicius A., \& Raudoniene. 2013. Toxin-producing fungi on feed grains and application of yeasts for their detoxification. Polish Journal of Veterinary Sciences 16(2): 391-393.

Rumerung S. N. 2015. Efek penggunaan konsentrat pabrikan dan buatan sendiri dalam ransum babi starter terhadap efisiensi penggunaan ransum. Zootek. ISSN Vol.35:295-301.

Taniwaki M. H., Imanaka B. T., \& Vicentini M. C. 2002. Fungus producing of ocratoxina and ocratoxina in coffees. Vol 1 Symposium research of coffees of Brazil.

Thrusfield M. 2006. Veterinary Epidemiology Third Edition. Oxford (GB): Blackwell Science.

Wang Y., Wang L., Wang Q., Selvaraj J. N., Xing F., Zhao Y., Liu F., \& Liu Y. 2016. Ochratoxin A producing fungi, biosynthetic pathway and regulatory mechanism. Toxins (Basel) 8(3): Article no. 83.

Widiastuti R. 2014. Residu aflatoksin dan metabolitnya pada berbagai produk pangan asal hewan dan pencegahannya. Wartazoa 24: 179-190.

Zhang Z., Gan F., Xue H., Liu Y., Huang D., Khab A. Z., Chen X., \& Huang K. 2015. Nephropathy and hepatopathy in weaned piglets provoked by natural ochratoxin $\mathrm{A}$ and involved mechanisms. Experimental Toxicologic Pathology 68(4): 205-213. 